\title{
Terapi Kognitif Perilaku dan Depresi Pasca Melahirkan
}

\section{Cognitive Behavior Therapy and Post-Partum Depression}

\author{
Haerani Nur Haeba \\ Rumah Sakit Jiwa, Kendari 93121 \\ Moordiningsih* \\ Fakultas Psikologi Universitas Muhammadiyah Surakarta, Surakarta 57102 \\ Diterima 5 April 2009 / Disetujui 20 Mei 2009
}

\begin{abstract}
This study is aimed to discover the effectiveness of cognitive behavior therapy towards post-partum depression. The reseach question of this study is whether or not cognitive behavior therapy can decrease post-partum depression The participants of this study are three mothers who are in the state of seven days to one month of post labour dan obtains a BDI pretest score between 16-23 which indicates moderate depression. Depression is measured with the Beck Depression Inventory. The result of this study shows that cognitive behavior therapy can reduce post-partum depression. The participants whom suffered from moderate post-partum depression showed a difference after acquired such therapy, whereas the participants does not show any symptoms of depression after being treated with cognitive behavior therapy.
\end{abstract}

Keywords: post-labour depression, cognitive behavior therapy, mothers

Kelahiran seorang bayi merupakan salah satu peristiwa yang paling membahagiakan dalam kehidupan perempuan. Kehadiran bayi menegaskan suatu status baru bagi seorang perempuan, yaitu menjadi seorang ibu. Adanya status baru ini di sisi lain ternyata menuntut ibu untuk melakukan berbagai penyesuaian. Salah satu bentuk penyesuaian yang harus dilakukan oleh seorang ibu yang baru melahirkan adalah mengikuti ritme kehidupan bayi. Ibu harus siap bangun tengah malam untuk menyusui atau mengganti popoknya yang basah. Keharusan untuk melakukan penyesuaian ini menyebabkan ibu sangat tertekan. Pada awal pengalaman sebagai ibu, perempuan merasakan berkurangnya kebebasan yang disebabkan oleh ketidakberdayaan dan ketergantungan dari bayi serta tuntutan untuk selalu mengurus dan memperhatikan bayi. Semua ini akan mengakibatkan stres baik secara fisik maupun psikologis (Kartono, 1992). Sebagian perempuan berhasil menyesuaikan diri pada tuntutan

* Penulis Korespondensi :

Hp.08156734566, Email : moordiningsih@yahoo.com 
dan peran tersebut secara baik, tetapi sebagian perempuan lain kurang dapat menyesuaikan diri. Hal inilah yang jika tidak diperhatikan akan dapat menimbulkan gangguan psikologis (www.postpartumstress.com, 01/03/06).

Kleiman (www.postpartumstress.com, 01/03/06) menunjukkan adanya pandangan stereotip terhadap ibu yang mengalami depresi pasca melahirkan. Mereka menganggap dirinya tidak beruntung, hidupnya terhambat dan tidak akan bahagia selamanya. Pandangan semacam ini dapat menyebabkan timbulnya perasaan tidak mampu, putus asa, tidak berharga, tidak percaya diri dan cemas yang akan menghambat mereka untuk mengurus diri, keluarga dan hubungan interpersonal.

Penelitian yang dilakukan Brown (Selby, 1980) membuktikan bahwa terjadinya depresi pasca melahirkan disebabkan oleh harapan-harapan dan keyakinan-keyakinan budaya. Di samping harus menyesuaikan diri dengan tuntutan-tuntutan bayi, ibu yang baru melahirkan juga harus mengakomodasi harapan budaya tentang persepsi seorang ibu yang dituntut menjaga kesehatan agar tetap bisa melayani suami. Hal ini menyebabkan ibu menjadi tidak suka terhadap peran baru sebagai ibu. Hal tersebut dapat menyebabkan ibu yang baru melahirkan menjadi tertekan.

Yalom, dkk. (Malonda, 2000) melengkapi kedua hasil penelitian di atas. Penelitian yang dilakukan mengaitkan terjadinya depresi pasca melahirkan dengan adanya tuntutan budaya reproduksi dalam hal-hal kondisi pengetahuan memelihara bayi, adanya peran baru sebagai ibu, kondisi siap tidaknya para ibu ketika bertambahnya anak sebagai beban ekonomi. Dalam penelitian tersebut ditemukan empat per lima dari para ibu yang mengalami depresi pasca melahirkan membutuhkan penanganan profesional.

Untuk membantu mengatasi depresi serta membuat prediksi agar lebih akurat tersebut, tampaknya terapi kognitif perilaku dapat dimanfaatkan sebagai salah satu jalan keluar. Dasar pemilihan terapi ini: (1) sesuai dengan teori-teori yang telah dikemukan di atas diketahui bahwa terjadinya depresi lebih disebabkan oleh adanya skema kognitif ataupun munculnya distorsi kognitif, dengan karakteristik berupa rendahnya penilaian terhadap diri sendiri dan tidak adanya keyakinan mengenai masa depannya. Proses kognisi akan mempengaruhi seseorang dalam berperilaku. Proses kognisi ini akan menjadi faktor penentu dalam menjelaskan bagaimana manusia berpikir, merasa dan bertindak. Kognisi merupakan proses yang memperantarai dalam proses belajar manusia. (2) Pikiran, perasaan dan tingkah laku saling berhubungan secara kausal. Dengan demikian pendekatan yang digunakan harus dapat mengatasi kecenderungan yang dialami penderita depresi tersebut. Terapi kognitif perilaku merupakan kombinasi strategi kognitif dan perilaku. Konsep dasar terapi ini adalah 
bahwa pola pemikiran manusia terbentuk melalui proses rangkaian stimulus-kognisi-respon, yang saling terkait dan membentuk jaringan dalam otak. Dengan demikian terdapat keselarasan dasar dalam pendekatan teori depresi dengan teori kognitif perilaku. (3) Dari hasil penelitian, banyak intervensi psikologi yang digunakan dalam menangani gangguan depresi. Penelitian-penelitian tersebut juga membandingkan antara satu intervensi psikologi dengan intervensi lainnya, seperti psikoterapi interpersonal (interpersonal psychotherapy) dengan maupun dengan terapi keluarga (family therapy). Hasil penelitian tersebut menunjukkan bahwa terapi kognitif perilaku merupakan salah satu terapi yang telah terbukti manjur untuk mengatasi depresi, khususnya depresi taraf sedang dan ringan bahkan berfungsi sebagai terapi jangka panjang (Brown, dkk., 1997; Mohr, dkk., 2001).

Beck (Oemarjoedi, 2004) menyatakan bahwa terapi kognitif perilaku dapat dimanfaatkan untuk mengatasi gangguan depresi berdasarkan atas pengalamannya dalam menangani pasien-pasiennya.

Mohr, dkk. (2001) menjelaskan terapi kognitif perilaku efektif diberikan pada subjek yang mengalami depresi dengan tingkatan rendah dan sedang, namun untuk subjek dengan tingkat depresi tinggi relatif lebih efektif bila digunakan farmakoterapi. Dengan memberikan penekanan terhadap metode berpikir, tampaknya terapi ini lebih mudah diterima subjek ini karena lebih memberikan kesempatan untuk mengekspresikan pikirannya secara bebas tapi terarah, serta modelnya yang semi terpusat pada klien (Oemarjoedi, 2004).

Penelitian lain juga dilakukan pada kasus gangguan kecemasan (anxiety disorder) pada anak dengan penelitian jangka panjang (long term research) menunjukkan hasil bahwa terapi kognitif perilaku merupakan terapi yang efektif berjangka panjang dalam menurunkan kecemasan (Barrett, dkk., 1996; 2001), juga kecemasan pada gay yang mengidap HIV positif (Anthony, dkk., 2000), kasus-kasus gangguan kecemasan umum (generalized anxiety disorder) (Borkovec, dkk., 2002; Stanley, dkk., 2003), pada kasus sindrom kelelahan kronis (chronic fatigue syndrome).

Terapi kognitif perilaku juga efektif dalam menangani kasus Gangguan Stres Pasca Trauma (Post Traumatic Stress Disorder) (Chemtob, dkk., 1997). Pada pikiran-pikiran obsesif juga didapatkan hasil bahwa terapi kognitif perilaku dapat menurunkan pikiran-pikiran obsesifnya (Freeston, dkk., 1997).

Lincoln, dkk. pada tahun 1997 dalam studi pendahuluannya (pilot study) mengevaluasi terapi kognitif perilaku untuk depresi pada penyandang cacat tubuh pasca stroke, di mana terbukti bahwa terapi kognitif perilaku yang diberikan dapat mengurangi tingkat depresi pada yang diderita (Lincoln, 2003). Penelitian Ewert, dkk. (Dell Orto \& Martrelli, 
1995) menyatakan terapi ini juga sukses untuk subjek yang mengalami cacat tubuh karena cidera otak (brain injury).

Di Indonesia penelitian tentang pengaruh terapi kognitif perilaku dalam menurunkan depresi pasca melahirkan belum pernah dilakukan. Retnowati (1990) meneliti pengaruh pemberian terapi kognitif dan terapi perilaku untuk menurunkan depresi pada mahasiswa.

Dengan mengacu pada penjelasan di atas, penelitian ini ingin menguji efektivitas terapi kognitif perilaku (cognitive behavior therapy) untuk mengatasi depresi pasca melahirkan.

Berdasarkan tinjauan pustaka dan landasan teori di atas, maka pertanyaan penelitian ini adalah: Apakah terapi kognitif perilakuan dapat mengurangi depresi pasca melahirkan?

\section{Metode Penelitian}

\section{Subjek Penelitian}

Kriteria utama yang dipakai untuk menentukan subjek penelitian adalah ibu-ibu yang telah ditentukan mengalami depresi pasca melahirkan. Penetapan subjek didasarkan pada:

1. DSM-IV (American Psychiatric Association (APA), 1994). Dalam DSM-IV dikatakan bahwa depresi pasca melahirkan termasuk dalam karegori depresi berat bila sedikitnya ada lima gejala selama periode dua minggu pengamatan yang disertai perubahan fungsi berupa: (a) Alam perasaan terdepresi atau mudah tersinggung dan (b) Hilangnya minat atau kesenangan, disertai sedikitnya empat gejala berikut:

a. Penurunan berat badan atau penurunan atau peningkatan nafsu makan

b. Insomnia atau hipersomnia hampir setiap hari

c. Agitasi atau retardasi psikomotor

d. Kelelahan atau kehilangan tenaga setiap hari

e. Perasaan tidak berharga atau rasa bérsalah yang berlebihan atau tidak

f. Hilangnya kemampuan untuk berpikir atau memusatkan perhatian, atau tidak dapat mengambil keputusan

g. Pikiran akan kematian yang berulang (recurrent), ide bunuh diri tanpa rencana khusus, atau usaha bunuh diri atau rencana khusus untuk melakukan bunuh diri.

Gejala tersebut harus menyebabkan penderitaan yang bermakna secara klinis atau gangguan dalam fungsi sosial, pekerjaan atau fungsi penting lain dan bukan karena efek fisiologis langsung dari suatu zat (misalnya obat yang disalahgunakan) atau kondisi medis umum (misalnya : hipotiroidisme).

Diagnosis depresi berat tidak dapat ditegakkan dalam dua bulan setelah 
kehilangan seseorang yang dicintai, kecuali jika ditemukan gangguan fungsional yang nyata, rasa tidak berharga, ingin bunuh diri, gejala psikotik atau retardasi psikomotor.

2. Berdasarkan PPDGJ III (Pedoman Penggolongan dan Diagnosis Jiwa Indonesia III, Maslim, 2002), depresi pasca melahirkan termasuk dalam Gangguan Depresi Berat tanpa Gejala Psikotik (F32.2), dengan kriteria :

a. Gejala utama : (1) Afek depresi, (2) Kehilangan minat dan kegembiraan, dan (3) Berkurangnya energi yang menuju meningkatnya keadaan mudah lelah dan menurunnya aktivitas.

b. Gejala lainnya: (1) Konsentrasi dan perhatian berkurang, (2) Harga diri dan kepercayaan diri berkurang, (3) Gagasan tentang rasa bersalah dan tidak berguna, (4) Pandangan masa depan yang suram dan pesimisme, (5) Gagasan atau perbuatan membahayakan diri atau bunuh diri, (6) Tidur terganggu, dan (7) Nafsu makan berkurang.

Pedoman diagnostik: a) Semua tiga gejala utama harus ada; b) Ditambah sekurang-kurang empat dari gejala lainnya dan beberapa di antaranya harus berorientasi berat; c) Bila ada gejala penting (misalnya agitasi atau retardasi psikomotor) yang mencolok, maka pasien mungkin tidak mau atau tidak mampu untuk melaporkan banyak gejalanya secara rinci; d) Gejala harus berlangsung sekurang-kurangnya dua minggu, akan tetapi jika gejala amat berat dan beromset sangat cepat, maka harus dibenarkan diagnosis dalam kurun waktu kurang dari dua minggu; e) Sangat tidak mungkin pasien akan mampu meneruskan kegiatan sosial, pekerjaan atau urusan rumah tangga, kecuali pada taraf yang sangat terbatas.

Karateristik subjek dalam penelitian ini adalah sebagai berikut:

a. Tingkat pendidikan minimal SMU; dimaksudkan agar subjek dapat memahami pertanyaan-pertanyaan dan pernyataan-pernyataan dalam penelitian. Selain itu agar subjek mampu melaksanakan aturan-aturan selama pemberian perlakuan.

b. Minimal tujuh hari-satu bulan pasca melahirkan.

c. Skor prates BDI berkisar 16-23 yang menunjukkan depresi sedang; maksud pemberian batas tingkat depresi ini agar setelah diberi perlakuan dapat dilihat secara jelas manfaatnya dalam menurunkan tingkat depresi.

Proses perolehan subjek dilakukan oleh peneliti pada tanggal 17-24 Juli 2006 dengan cara menelusuri catatan medis rawat inap (kebidanan) ibu yang melahirkan satu bulan terakhir di "Klinik Bersalin Anna" Kendari. Berdasarkan data yang diperoleh dari catatan medik, ibu yang melahirkan satu bulan terakhir berjumlah 28 orang, namun yang memenuhi kriteria yang 
ditentukan hanya 19 orang.

Peneliti selanjutnya menelusuri kediaman 19 subjek berdasar alamat yang diperoleh dari catatan medis tempat subjek melahirkan, bersama dengan dua orang sukarelawan yang memerlukan waktu sekitar tujuh hari. Alamat yang berhasil ditemukan hanya berjumlah 14 orang. Hal tersebut disebabkan daerah Kendari terdiri atas pulau-pulau kecil yang dipisahkan oleh lautan, sehingga susah untuk dijangkau. Subjek yang berhasil ditemui tersebut kemudian diminta kesediaannya untuk mengisi angket identitas dan skala BDI dengan terlebih dahulu diberi penjelasan tentang penelitian yang akan dilakukan beserta tujuannya. Dalam prates BDI tersebut didapatkan hasil sebagaimana tabel berikut:

Tabel 1. Diskripsi data prestest BDI

\begin{tabular}{lcc}
\hline \multicolumn{1}{c}{ Kategori } & Skor BDI & Jumlah \\
\hline Tidak ada gejala & $0-5$ & 7 \\
Ringan & $6-15$ & 4 \\
Sedang & $16-23$ & 3 \\
Berat & $24-63$ & - \\
\hline
\end{tabular}

Berdasarkan skor BDI, subjek yang memenuhi kriteria penelitian berjumlah tiga orang. Selanjutnya peneliti-kembali menghubungi subjek untuk dimintai kesediaan mengikuti penelitian. Ketiga subjek bersedia mengikuti penelitian.

\section{Rancangan Penelitian}

Desain penelitian ini adalah sebagai berikut:

$$
\begin{array}{llll}
\mathrm{Y} 1 & \mathrm{X} & \mathrm{Y} 2 & \mathrm{Y} 3
\end{array}
$$

Keterangan :

$\mathrm{Y} 1$ = Prates

$X=$ Terapi kognitif perilakuan

$\mathrm{Y} 2$ = Pascates

$\mathrm{Y} 3$ = Pengukuran tindak lanjut (2 minggu setelah pemberian perlakuan)

\section{Pengumpulan Data}

Alat ukur yang digunakan untuk mengetahui keberhasilan terapi kognitif perilaku adalah:

a. Hasil Beck Depression Inventory saat prates, pascates dan dua minggu setelah pemberian perlakuan 
b. Hasil tugas rumah yang diberikan setiap sesi pertemuan

Selanjutnya, evaluasi hasil intervensi yang telah dilakukan dianalisis dengan menggunakan metode deskriptif - kualitatif. Diharapkan dengan metode analisis deskriptif dapat mendeskripsikan atau menggambarkan secara menyeluruh dan sistematis mengenai perkembangan selama pemberian perilaku, serta pengaruh pemberian terapi kognitif perilaku terhadap depresi subjek setelah dilakukan satu kali amatan ulangan atas pengaruh terapi tersebut yaitu pada saat pascates dan dua minggu setelah follow up.

Intervensi

Konsep dasar prosedur pelaksanaan terapi diambil dari prosedur "coping with depression course" yang disusun dan dikembangkan oleh Brown dkk. (1997). Oleh Brown dkk. komponen-komponen yang diajarkan pada subjek berupa pemberian perlakuan (treatment) rasional, penilaian perasaan, meningkatkan aktivitas menyenangkan dan teknik $A B C$, meningkatkan pikiran positif-mengurangi pikiran negatif, keterampilan sosial-asertif serta mempertahankan keterampilan efektif. Materi ini telah teruji sebagai perlakuan yang efektif untuk mengatasi depresi unipolar, depresi pada remaja, depresi pada penderita diabetes tipe II dan juga sebagai perlakuan yang efektif dalam menurunkan depresi pada pecandu alkohol (alcoholism) (Brown dkk., 1997). Materi "coping with depression course" ini pertama kali dibuat dan dipublikasikan oleh Brown \& Lewinsohn (1984) dalam buku "Coping with Depression: Course Workbook".

Aplikasi dalam mengatasi depresi akan diterapkan dengan memberikan pekerjaan rumah setiap hari untuk menerapkan ketrampilan yang telah diajarkan. Agar program intervensi berjalan dengan baik dan dapat mencapai hasil maksimal, pelaksanaan program ini dibantu oleh satu tenaga psikolog sebagai tenaga profesional. Pemberian terapi dilaksanakan secara berkelompok selama enam sesi, setiap minggu dua kali sesi, setiap pertemuan dilaksanakan selama 45-60 menit. Selama mendapatkan terapi, subjek diberi tugas-tugas untuk dikerjakan sebagai pekerjaan rumah dan akan dibahas bersama dalam proses terapi. Selama terapi, psikolog didampingi oleh pengamatan (observer). Berdasarkan kesepakatan antara terapis dan subjek, pelaksanaan pemberian terapi dilakukan dua kali dalam seminggu yaitu setiap hari rabu dan sabtu, mulai pukul 16.00 sampai dengan 17.00 berlokasi di ruang rehabilitasi Rumah Sakit Jiwa Kendari yang dimulai pada tanggal 2 Agustus sampai dengan 19 Agustus 2006 . 


\section{Metode Analisis Data}

Penelitian ini menggunakan metode kuantitatif dan analisis data. Metode kualitatif merupakan prosedur penelitian yang menghasilkan data deskriptif berupa kata-kata tertulis atau lisan dari orang-orang dan perilaku yang dapat diamati (Bogdan dan Taylor, dalam Moleong, 2002).

\section{Hasil Penelitian}

\section{Hasil Analisa Data}

Berdasarkan tes Beck Depression Inventory yang diberikan sebelum pemberian perilakuan diperoleh hasil sebagai berikut:

Tabel 2. Hasil prates Skor BDI Subjek

\begin{tabular}{ccc}
\hline Nama & Skor & Tingkat Depresi \\
\hline Subjek A & 21 & Sedang \\
Subjek B & 17 & Sedang \\
Subjek C & 20 & Sedang \\
\hline
\end{tabular}

Selanjutnya, berdasarkan interpretasi tes SSCT tentang penyesuaian konsep diri pada subjek A diperoleh gambaran bahwa subjek merasa takut terhadap masa depan keluarganya yang kurang harmonis. Ketakutan ini membuat subjek berpikir untuk mati karena merasa tidak sanggup membina keluarganya. Tergambar pula bahwa ada rasa bersalah karena tidak bisa menjadi isteri yang baik dalam melayani suami dan perasaan kecewa terhadap sikap suami. Subjek juga menguraikan bahwa masa depannya suram karena beranggapan bahwa ia akan kehilangan suami sehingga ia akan harus membesarkan anakanaknya sendiri. Skor yang diperoleh subjek A pada masing-masing item di atas adalah 2, artinya subjek $\mathrm{A}$ mengalami hambatan pada penyesuaian konsep diri dan memerlukan penanganan.

Berdasarkan interpretasi tes SSCT tentang penyesuaian konsep diri pada Subjek B diperoleh gambaran bahwa ada ketakutan akan kegagalan dalam kehidupan rumah tangga, namun subjek menganggap bahwa apa yang dialami merupakan ujian Allah 'azza wa jalla dan subjek harus bersabar. Tergambar pula bahwa ada rasa bersalah karena pernah membantah suami dan tidak bisa menjadi istri yang baik, namun subjek berusaha untuk selalu memperbaiki diri. Subjek menguraikan bahwa masa depan tidak dilihat dari kemampuan ekonomi tetapi terbentuknya keluarga sakinah yang penuh kasih sayang. Skor yang diperoleh Subjek B pada masing-masing item di atas adalah 1 , artinya subjek B mengalami sedikit 
gangguan dalam penyesuaian konsep diri, namun subjek masih mampu untuk mengatasi hal tersebut sendiri.

Berdasarkan interpretasi tes SSCT tentang penyesuaian konsep diri pada Subjek C diperoleh gambaran adanya ketakutan pada masa depan yang suram sehingga ada keinginan untuk mati. Subjek selalu dihantui pikiran bahwa ajalnya akan segera tiba. Tergambar pula bahwa subjek merasa tertekan dan kurang bahagia di masa kanak-kanaknya sehingga bagi subjek masa kecil merupakan hal yang tidak menarik untuk dibicarakan. Skor yang diperoleh subjek $\mathrm{C}$ pada masing-masing item di atas adalah 2 , artinya subjek $\mathrm{C}$ mengalami hambatan pada penyesuaian konsep diri dan memerlukan penanganan.

Sebelum mendapat terapi kognitif perilaku, subjek A mendapat skor BDI 21 dengan kategori depresi sedang. Adapun gejala-gejala yang menonjol terdapat pada pernyataan yang mendapat skor 2, yaitu pernyataan A yang berbunyi "Saya merasa begitu sedih dan tidak bahagia, sehingga keadaan ini sangat menyiksa", pernyataan $\mathrm{C}$ yang berbunyi "Kalau saya meninjau kembali hidup saya, yang dapat saya lihat hanyalah banyaknya kegagalan", pernyataan E yang berbunyi "Saya benar-benar merasa bersalah", pernyataan I yang berbunyi "Saya merasa lebih baik saya mati saja" dan pernyataan $\mathrm{J}$ yang berbunyi "Saya menangis sepanjang waktu, saya tidak dapat menghentikannya". Hasil tes BDI tersebut didukung oleh interpretasi yang diperoleh dari tes SSCT tentang penyesuaian konsep diri subjek. Terlihat bahwa Subjek A merasa takut terhadap masa depan keluarganya yang kurang harmonis karena suami sudah tidak peduli terhadap keluarga. Ketakutan ini membuat subjek berpikir untuk mati karena merasa tidak sanggup membina keluarganya. Tergambar pula bahwa ada rasa bersalah karena gagal menjadi isteri yang baik dalam melayani suami dan perasaan kecewa terhadap sikap suami yang tidak peduli terhadap keluarganya. Subjek berpikir bahwa masa depannya suram karena beranggapan akan kehilangan suami dan akan membesarkan anak-anaknya sendiri.

Subjek B, sebelum mendapat terapi kognitif perilaku mendapat skor 17 dengan kategori depresi sedang. Adapun gejala-gejala yang menonjol terdapat pada pernyataan $\mathrm{C}$ dengan skor 2 yang berbunyi "Saya merasa baru sedikit mencapai sesuatu yang berharga atau berarti", pernyataan $\mathrm{H}$ dengan skor 3 yang berbunyi "Saya menyalahkan diri saya sendiri atas segala keburukan yang telah terjadi" dan pernyataan $\mathrm{J}$ dengan skor 2 yang berbunyi "Saya menangis sepanjang waktu dan tidak dapat menghentikannya". Hasil tes BDI tersebut didukung oleh interpretasi yang diperoleh dari tes SSCT tentang penyesuaian konsep diri subjek. Tergambar bahwa adanya ketakutan pada diri subjek $B$ akan kegagalan dalam kehidupan rumah tangganya karena sikap suami yang tidak peduli pada keluarga, namun 
subjek menganggap bahwa apa yang dialami merupakan ujian Allah dan dia harus bersabar. Tergambar pula bahwa ada rasa bersalah karena pernah membantah suami dan tidak bisa menjadi isteri yang baik, namun subjek akan berusaha untuk memperbaiki diri.

Subjek C, sebelum mendapatkan terapi kognitif perilaku mendapat skor 20 dengan kategori depresi sedang. Adapun gejala-gejala yang menonjol terdapat pada aitem-aitem yang mendapat skor 2, yaitu item A "Saya menangis sepanjang waktu dan tidak dapat menghentikannya", item L "Saya telah kehilangan sebagian besar perhatian saya terhadap orang lain dan hanya sedikit tertarik pada terhadap mereka", dan item I "Saya merasa lebih baik saya mati saja". Hasil tes BDI lebih jauh dapat diketahui dari hasil tes SSCT bahwa adanya keinginan untuk mati disebabkan ketakutan akan masa depan yang suram karena kondisi ekonomi yang belum stabil dan kurangnya perhatian dari keluarga. Hal tersebut menyebabkan subjek selalu merasa bahwa ajalnya akan segera tiba.

\section{Hasil Evaluasi}

Hasil evaluasi keseluruhan. Berdasarkan perbandingan dari hasil pengukuran yang dilakukan pada saat prates dan pascates diperoleh data yang menunjukkan adanya penurunan skor tingkat depresi dari ketiga subjek penelitian dan masih dapat bertahan setelah dua minggu pemberian perlakuan. Hal ini dapat dilihat dari perbedaan skor prates lebih tinggi dibandingkan skor pascates dan dua minggu setelah pengukuran. Selanjutnya dalam memberi makna pada masing-masing skor tersebut peneliti mengacu pada tabel tingkat depresi dan tingkat keluhan depresi juga batasan skor yang dapat menunjukkan bahwa subjek mengalami depresi atau tidak berdasarkan Beck Depression Inventory, lanjut rinciannya sebagai berikut:

Tabel 3. Skor Perubahan BDI Subjek

\begin{tabular}{ccccc}
\hline Nama & $\begin{array}{c}\text { Skor Prates/ } \\
\text { Indikator }\end{array}$ & Skor Pascates/ Indikator & $\begin{array}{c}\text { Gain } \\
\text { Score }\end{array}$ & $\begin{array}{c}\text { Skor Follow Up/ } \\
\text { Indikator }\end{array}$ \\
\hline Subjek A & 21 (Sedang) & 4 (Tidak ada gejala depresi) & 17 & 2 (Tidak ada gejala depresi) \\
Subjek B & 17 (Sedang) & 2 (Tidak ada gejala depresi) & 15 & 0 (Tidak ada gejala depresi) \\
Subjek C & 20 (Sedang) & 1 (Tidak ada gejala depresi) & 19 & 0 (Tidak ada gejala depresi) \\
\hline
\end{tabular}

Berdasarkan hasil prates BDI diketahui adanya simtom depresi tingkat sedang yang dialami subjek $A$ dengan skor 21, subjek $B$ dengan skor 17 dan subjek $C$ dengan skor 20 . Sebaliknya, untuk skor pascates subjekA memiliki skor 4, subjek B memiliki skor 2 dan subjek C memiliki skor 1 , artinya masuk dalam kategori tidak ada gejala depresi, namun masih ada 
keluhan ringan. Selanjutnya, pada dua minggu setelah pemberian perlakuan skor subjek $A$ menunjukkan angka 2 dan subjek $B$ menunjukkan skor 2, artinya masuk dalam kategori tidak ada gejala depresi, namun masih ada keluhan ringan dan pada subjek $C$ menunjukkan skor 0 , artinya dalam kategori tidak ada sama sekali gejala depresi. Hal tersebut menunjukkan bahwa adanya pengaruh pemberian terapi kognitif perilaku dalam menurunkan tingkat depresi pada ketiga subjek.

Berdasarkan tabel di atas, tergambar pula bahwa di antara ketiga subjek, Subjek $\mathrm{C}$ memperoleh skor depresi lebih tinggi, yaitu 19 poin, lalu SubjekA dengan 17 poin dan Subjek B dengan 15 poin. Artinya, Subjek $C$ memperoleh prestasi lebih tinggi dengan kemampuan menurunkan tingkat depresi sampai 19 poin, selanjutnya subjek $A$ dengan kemampuan menurunkan tingkat depresi sampai 17 poin dan subjek $B$ dengan kemampuan menurunkan tingkat depresi sampai 15 poin. Walau demikian, ketiga subjek mampu menurunkan tingkat depresi dari tingkat sedang menjadi tidak ada gejala depresi.

Selanjutnya, pada lembar kerja analisis masalah, ketiga subjek mampu meminimalkan beban depresi dari sangat terbebani menjadi sedikit terbebani dengan adanya bukti yang tidak mendukung pikiran negatif. Demikian halnya pada lembar kerja catatan suasana hati harian, ketiga subjek mampu mengidentifikasi suasana hati harian, mengatasi pikiran menyimpang penyebab depresi serta memahami faktor yang mempengaruhi suasana hati tersebut, sehingga menciptakan pikiran rasional dan bisa mengurangi beban depresi yang dialami. Hal tersebut menunjukkan bahwa dengan pembuatan lembar analisis masalah dan membuat catatan suasana hati harian mampu mengubah pikiran negatif menjadi pikiran positif.

Ketiga subjek juga mampu membuat jadwal aktivitas yang menyenangkan. Subjek $A$ mampu meningkatkan frekuensi jadwal aktivitas menyenangkan dengan kualitas cukup menyenangkan hingga sangat menyenangkan baik yang dilakukan sendiri maupun bersama suami dan anak-anak. Demikian hainya Subjek B. Subjek B mampu meningkatkan frekuensi aktivitas menyenangkan dengan kualitas cukup menyenangkan hingga sangat menyenangkan yang lebih banyak dilakukan sendiri, bersama ibu dan anak-anak dan hanya satu aktivitas yang dilakukan bersama suami. Pada Subjek $C$ frekuensi aktivitas menyenangkan yang dilakukan lebih sedikit dibanding subjek $A$ dan subjek $B$, tetapi memiliki kualitas sangat memuaskan, baik yang dilakukan sendiri maupun bersama suami. Hal tersebut menunjukkan bahwa ketiga subjek mampu menciptakan aktivitas menyenangkan.

Melalui lembar identifikasi pikiran positif dan negatif, ketiga subjek mampu mengelola diri secara kognitif untuk mengurangi pikiran negatif dan menggunakan pikiran positif. Pada 
kasus pertama, SubjekA masih didominasi pikiran negatif sehingga masih memberi efek yang mengganggu pada emosi, kognisi dan perilaku, tetapi pada kasus kedua hal tersebut sudah mampu diminimalkan tetapi masih cukup mengganggu dan pada kasus ketiga, empat dan lima, subjek sudah mampu mengelola diri secara kognitif dan sudah mampu menggunakan pikiran positif sehingga akibat dari situasi yang menekan mampu diminimalkan dan hanya sedikit mempengaruhi emosi, kognisi dan tingkah laku. Demikian halnya Subjek B dan Subjek C, mampu mengelola diri secara positif sehingga akibat dari situasi stresor dapat diminimalkan dari cukup mengganggu menjadi tidak mengganggu emosi, kognisi dan tingkah laku. Hal tersebut menunjukkan bahwa subjek mampu mengidentifikasi pikiran positif dan negatif.

Melalui lembar kerja "Rencana Kerja" ketiga subjek mampu membuat daftar situasi stresor dan bersikap lebih asertif dalam merespon situasi tersebut. Ketiga subjek mampu menentukan permasalahan yang harus dipecahkan dengan orang lain. Berdasarkan prediksi waktu yang telah ditetapkan, subjek mampu menyelesaikan masalah dengan keterampilan asertif. Hal tersebut menunjukkan bahwa subjek mampu bersikap asertif dan meningkatkan hubungan sosial dengan orang lain.

Berdasarkan uraian di atas, dapat disimpulkan bahwa terapi kognitif perilaku mampu menurunkan tingkat depresi. Dengan terapi kognitif perilaku terjadi perubahan pikiran negatif menjadi pikiran positif, mampu menciptakan aktivitas yang menyenangkan, mampu mengidentifikasi pikiran positif dan negatif serta mampu bersikap asertif dan meningkatkan kualitas hubungan sosial.

\section{Pembahasan}

Berdasarkan hasil analisis data pengukuran Beck Depression Inventory (BDI) pada subjek A diketahui bahwa saat prates Subjek A memperoleh depresi dengan skor 21 yang menunjukkan adanya gangguan depresi tingkat sedang. Bila dibandingkan dengan hasil pascates di mana Subjek A memperoleh skor 4, maka hal itu menunjukkan hasil tidak adanya gangguan atau menunjukkan tidak adanya gejala depresi menurut acuan pada tabel derajat depresi dan tingkat keluhan depresi. Begitu juga setelah dua minggu pasca pemberian perlakuan memperoleh skor 2 menujukkan tidak adanya gejala depresi. Hal ini berarti pengaruh pemberian perlakuan dapat bertahan.

Pada subjek B saat prates dicapai skor 17. Hal ini menunjukkan adanya gangguan depresi tingkat sedang dan ini dibandingkan dengan hasil pascates menjadi 2 . Ini menunjukkan tidak adanya gangguan atau menunjukkan tidak adanya gejala depresi menurut acuan pada tabel derajat depresi dan tingkat keluhan depresi. Begitu juga setelah dua minggu 
pasca pemberian perlakuan memperoleh skor 0 menunjukkan tidak adanya gejala depresi. $\mathrm{Hal}$ ini berarti bahwa pengaruh pemberian perlakuan dapat bertahan. Demikian halnya pada subjek C, saat prates dengan skor 20 menunjukkan adanya gangguan depresi tingkat sedang dan ini dibandingkan dengan hasil pascates menjadi 1 menunjukkan tidak adanya gangguan atau menunjukkan tidak adanya gejala depresi menurut acuan pada tabel derajat depresi dan tingkat keluhan depresi. Begitu juga setelah dua minggu pasca pemberian perlakuan memperoleh skor 0 menunjukkan tidak adanya gejala depresi. Hal ini berarti pengaruh pemberian perlakuan dapat bertahan.

Hasil analisis data di atas membuktikan bahwa terapi kognitif perilaku efektif bila diberikan pada penderita depresi pasca melahirkan tingkat ringan dan sedang. Diskusi dan tugas-tugas rumah yang diberikan melatih subjek untuk memiliki kemampuan mengatasi masalah dan mengubah cara berfikirnya menjadi lebih "adaptive". Pendekatan kognitif perilakuan lebih memfokuskan pada proses berfikir dan bagaimana hal itu mempunyai kontribusi terhadap perilaku dan emosi maladaptif.

Kurangnya dukungan sosial yang diperoleh, terutama dari suami, merupakan faktor utama yang melatar belakangi terjadinya depresi pada ketiga subjek. Kondisi tersebut telah dibuktikan sebelumnya oleh Chollins, dkk. (1993), dalam studinya yang menguji efektivitas dukungan sosial bagi ibu hamil dan melahirkan. Hasil studinya membuktikan bahwa dukungan sosial efektif meningkatkan kesehatan ibu dan bayi yang dilahirkan. Lebih lanjut Wan, dkk. (1998) memperjelas bahwa dengan dukungan sosial, wanita merasa kehadirannya memberi arti penting dalam struktur keluarga.

Selain dukungan sosial yang kurang dari suami dan keluarga, faktor ekonomi juga merupakan salah satu faktor pemicu terjadinya depresi pasca melahirkan. Leopold, dkk. (2004) mengemukakan bahwa bertambahnya beban ekonomi karena kelahiran anggota baru merupakan salah satu faktor terjadinya depresi pasca melahirkan. Pendapat tersebut didukung oleh hasil survei Badan Pusat Statistik yang menunjukkan bahwa 16, 1 persen kelahiran tidak dikehendaki karena alasan ekonomi. Hal tersebut dialami oleh Subjek C, dimana depresi pasca melahirkan yang dialami Subjek $\mathrm{C}$ dilatarbelakangi oleh kurangnya dukungan keluarga dan kondisi ekonomi yang belum mapan.

Selain itu, subjek selalu menilai setiap kejadian sebagai sesuatu yang negatif dan menyebabkan tekanan, tekanan yang dialami dianggap subjek sebagai kegagalan dirinya dan akan merusak masa depan. Pendapat negatif subjek tersebut sesuai dengan apa yang diutarakan oleh Beck (1985) bahwa suatu pengalaman yang sama akan mempengaruhi dua orang dengan cara yang berlainan. Perbedaan ini sangat dipengaruhi oleh cara pandang 
individu yang bersangkutan terhadap sebuah peristiwa. Cara pandang atau interpretasi dari kognisi yang sering keliru adalah melibatkan distorsi negatif terhadap pengalaman hidup, penilaian diri yang negatif, pesimisme, dan keputusasaan. Pandangan negatif yang dipelajari ini selanjutnya menyebabkan perasaan depresi (Kaplan dkk., 1991), depresi didahului oleh kekacauan atau gangguan pada pikirannya yang kemudian mendasari gangguan pada perasaannya (Sue dkk, 1986). Mereka lebih mengharapkan kegagalan dari pada keberhasilan, cenderung menonjolkan dan membesarkan kegagalan, mengecilkan arti keberhasilan, serta suka menyalahkan diri sendiri pada suatu situasi yang kurang beres (Atkinson dkk., 1999).

Oleh karena itu, tujuan dari terapi kognitif perilaku adalah untuk mengubah proses berpikir individu agar menjadi lebih rasional dengan menggunakan prinsip dan hukum perilaku pada umumnya. Di samping itu terapi ini juga bertujuan agar individu yang depresif mempunyai kemampuan untuk mengenali dan kemudian mengevaluasi atau mengubah cara berpikir, mengubah keyakinan dan perasaannya (mengenai diri sendiri dan lingkungan) yang salah sehingga mereka dapat mengubah perilaku yang maladaptife dengan cara mempelajari ketrampilan pengendalian diri dan strategi pemecahan masalah yang efektif (Okun, 1990).

Tujuan dari terapi terapi kognitif perilaku pada penelitian ini dapat dijalankan dengan optimal oleh subjek. Seperti pada tugas rumah pertama (lembar kerja analisis masalah), subjek menjadi mampu melakukan analisis masalah melalui pengenalan terhadap situasi dan perasaannya pada saat itu, pikiran negatif yang muncul ketika mengalami situasi stresor, mampu mencari bukti yang mendukung pikiran negatif dan mampu menemukan bukti yang tidak mendukung pikiran negatif. Hal tersebut menyebabkan subjek menemukan pikiranpikiran baru yang lebih positif dan mendapatkan perasaan baru yang lebih positif pula. Begitu pula pada tugas rumah kedua (lembar kerja analisis masalah), subjek menjadi mampu mengidentifikasi dan memonitor suasana hati hariannya, mampu mengidentifikasi pikiran yang menyimpang dan menemukan faktor penyebab dari suasana hatinya tersebut. Pada kegiatan tugas rumah ketiga (daftar aktivitas yang menyenangkan), subjek menjadi mampu membuat jadwal aktivitas positif yang menyenangkan, memonitor dan berusaha meningkatkan aktivitas menyenangkan tersebut. Selanjutnya, pada tugas rumah keempat, subjek menjadi mampu memantau pikiran dan mengidentifikasi pikiran negatif dan positif serta mampu mengelola diri secara kognitif untuk mengurangi bahkan menghentikan pikiran negatif. Demikian halnya pada tugas kelima, dari hasil yang diperoleh terbukti bahwa subjek mempunyai keterampilan baru dalam meningkatkan kualitas hubungan sosial dan merespon secara asertif situasi stresor. 
Perlu diketahui, terjadinya penurunan tingkat depresi yang dialami subjek disebabkan keinginan yang sangat besar dari subjek untuk sembuh, kemampuan subjek untuk melakukan tugas-tugas yang diberikan dan tidak terlepas dari kemampuan terapis dalam memberikan terapi.

Di dalam penelitian ini ada beberapa keterbatasan. Keterbatasan penelitian dapat digunakan sebagai antisipasi untuk penelitian selanjutnya. Beberapa keterbatasan penelitian ini adalah sebagai berikut:

1. Keterbatasan jumlah subjek penelitian sehingga tidak bisa dilakukan perbandingan lebih banyak tentang perubahan pada setiap subjek. Hal tersebut disebabkan penderita depresi pasca melahirkan jarang ditemukan. Selain itu, cukup rumitnya pelaksanaan prosedur terapi kognitif perilakuan membatasi kriteria subjek penelitian pada tingkat pendidikan di atas SMU, padahal penderita depresi pasca melahirkan bisa dialami oleh setiap ibu melahirkan tanpa melihat tingkat pendidikan. Di sisi lain, letak geografis daerah Sulawesi Tenggara yang dipisahkan oleh pulau-pulau kecil dan susah dijangkau merupakan penghambat untuk menelusurikeberadaan subjek penelitian.

2. Tidak ada Informed Consent (persetujuan dari subjek untuk mendapat terapi). Hal tersebut karena sudah adanya kepercayaan subjek pada terapis, padahal Informed Consent penting untuk menjaga kemungkinan adanya resiko atau efek merugikan dari subjek penelitian terhadap subjek penelitian.

\section{Simpulan dan Rekomendasi}

\section{Simpulan}

Berdasarkan hasil analisis penelitian yang telah dikemukakan, dapat ditarik kesimpulan bahwa terapi kognitif perilaku dapat menurunkan depresi pasca melahirkan.

\section{Rekomendasi}

Dari hasil penelitian ini, ada beberapa rekomendasi yang dapat dikemukakan, antara lain:

1. Lembaga-lembaga yang menangani kesehatan ibu hamil, bersalin dan setelah melahirkan (klinik bersalin, puskesmas dan rumah sakit jiwa). Program terapi ini dapat dimanfaatkan sebagai salah satu model intervensi bagi penanganan pasien depresi.

2. Peneliti selanjutnya yang ingin melakukan replikasi pada penelitian ini, disarankan untuk melakukan terapi kognitif perilaku kepada responden yang jumlahnya lebih besar sehingga dapat membandingkan dan mengetahui variasi perubahan pada masingmasing subjek. 
3. Peneliti selanjutnya, diharuskan adanya bukti tertulis kesediaan subjek mengikuti proses terapi. Hal tersebut adalah menjaga kemungkinan adanya resiko atau efek merugikan dari penelitian terhadap subjek penelitian.

4. Peran psikolog diharapkan dapat memberi pelayanan yang lebih singkat dan mudah sehingga dapat diberikan pada setiap penderita depresi.

\section{Daftar Pustaka}

American Psychiatric Association, 1994. Diagnostic and Statistical Manual of Mental Disorders (DSM-IV). Edisi ke-4. Washington: Donnelly \& Sons Company.

Atkinson, R.L., Atkinson, R.C., \& Hilgard, E. 1999. Pengantar Psikologi. Jakarta : Erlangga.

Anthony, M. H. Cruess, D. G., Cruess, S. Lutgendorf, S., Kumar, M., Ironson, G., Klimas, N., Flethcher, M. A., Schneiderman, N. (2000). Cognitive-Behavioral Stress Management Intevension Effect on Anxiety, 24-Hr Urinary Norepinephrine Output, and T-Cytotoxic/ Suppressor Celss Over Time Among Symptomatic HIC-Infected Gay Men. Journal of Consulting and Clinical Psychology, 68, 3145.

Beck, A.T. 1979. Cognitive Therapy and the Emotional Disorders. Botton: International Universities Press Inc.

Beck, A.T. 1985. Depression: Causes and Treatment. Philadelphia: University of Pennsyivania Press.

Borkovec, T. D., Newman, M. G., Pincus, A. L., Lytle, R. (2002). A Componen Analysis if Cognitive-Behavioral Therapy fo Generalized Anxiety Disorder and the Role of Interpersonal Problem. Journal of Consulting and Clinical Psychology, 70 (2), 288 298.

Brown, R. A., Evan, D. M., Miller, I. W., Burgess, E. S., Umeller, T. I. (1997). CognitiveBehavioral Treatment for Depression in Alcoholism. Journal of Consulting and Clinical Psychology, 65, 715-726.

Chemtob, C.M., Novaco, R.W., Hamada, R.S., \& Gross, D.M. 1997. Cognthive-Behavioral Treaatment of Severe Anger in Posttraumatic Stress Disorder. Journal of Consulting and Clinical Psychology, 65, 184-189.

Collins, N.L., Schetter, C.N., Label, M., dan Scrimshaw, C.M. 1993. Social Support in Pregnancy: Psychosocial Corellates of Borth Outcomes in Medically High-Risk Women. Journal Health Psychology, 19, 544-553.

Fresston, M.H., Ladouceur, R., \& Gagnom, F. 1997. Cognitive-Behavior Treatment of Closessive Thoughts : A Controlled Study. Journal of Consulting and Clinical Psychology, 65, 405-413.

Kaplan, H.I., Sadock, B.J., Grebb, J.A. 1991. Sinopsis Psikiatri: IImu Pengetahuan Perilaku Psikiatri Klinis. Edisi Tujuh. (Alih bahasa: Widjaja Kusuma). Jakarta: Fakultas Kedokteran Universitas Tri Sakti. 
Kaplan, H.I., \& Sadock, B.J. 1991. Buku Saku: Psikiatri Klinik. Jakarta: BinarupaAksara.

Kartono, K. 1992. Psikologi Wanita. Mengenal Wanita dan Nenek. Bandung: Mandar Maju.

Kleiman, K. 2003. The Postpartum Stress Center. Diunduh pada 01 Maret, 2006 dari http://www.postpartum stress.com/about.ppsc.html.

Leopold, K.A., Zoschnick, L.B. 2004. Postpartum Depression. Women's Primary Health Grand Rounds at the University of Michigan.

Lincoln, N.B., FLannagan, T. 2003. Cognitive Behavior Psychotherapy for Depression Fllowing Stroke. Stroke, 34, 111-115.

Lincoln, N.B., FLannagan, T., Sutcliffle, L., \& Rother, L. 1997. Evaluation of Cognitive Behavior Treatment for Depression After Stroke : A Pilot Study. Clinical Rehabilitation, 11, 114122.

Malonda, F. 2000. Manfaat Riset Kesehatan Maternal. (Artikel).

Martin, G., \& Pear, J. 1996. Behavior Modification : What It Is and How to Do It. New Jersey: Prentice Hall, Inc.

Maslim, R. 2002. Buku Saku Diagnosis Gangguan Jiwa. Rujukan Ringkas dari PPDGJ- III. Jakarta.

Maleong, L.J. 2002. Metodologi Penelitian Kualitatif. Bandung : Remaja Rosdakarya.

Mohr, D. C., Likosky, W., Dick, L. P., Van Der Wende, J., Dwyer, P., Bertagnolli, A. C., \& Goodkin, D. E. (2000). Telephone-administered cognitive-behavioral 188 therapy for the treatment of depressive symptoms in multiple sclerosis. Journal of Consulting and Clinical Psychology, 68, 356-361.

Oemarjoedi, A. K. (2004). Pendekatan Cognitive Behavior dalam Psikoterapi. Jakarta : Penerbit Creative Media.

Okun B. F. 1990. Seeking Connection in Psychotherapy. San Francisco \& Oxford: JosseyBass Publishers Pruot. H. T., \& Brown, D. T. (1985). Counseling and Psychotherapy With Childern and Adolescents : Theory and Practice For School ang Clinical Settings. Brandon, Vermont: Clinical Psychology Publishing Co, Inc.

Retnowati, S. 1990. Efektivitas Terapi Kognitif dan Terapi Perilaku Pada Penanganan Gangguan Depresi. Tesis (tidak diterbitkan). Yogyakarta: Fakultas Psikologi UGM.

Ronen, T. 1997. Cognitive Development Therapy with Children. New York: John Woley \& Sons.

Selby, J.A., \& James, A. 1980. Psychology and Human Reproduction. London: Collier Macmillan Publishers.

Stanley, M.A., Hopko, D.R. Diefenbach, 6 J., Bourland, S.L., Rodriguez, H., \& Wagener, P. 2003. Cognitive-Behavior Therapy for Late-life Generalized Anxlety Disorder 
inPrimary Care : Preliminary Findings. The American Journal of Geriatric Psychiatry: Offficial Journal of the American Associaton for for Gerlatric Psychiatry, 11, 92-96

Sue, D,. Sue, D., \& Sue, S. 1986. Understanding Abnormal Behavior. Boston: Houghton Mifflin Company.

Wan, C.K., Jaccard, J., \& Ramey, S.L. 1991. The Relationship Between Social Support and Life Satisfaction as a Function of Family Structure. Journal of Marriage and the Family, 1,502-513. 